\title{
HOW TO PROTECT RIGHTS BY INFORMING ABOUT RIGHTS? SOME REMARKS ABOUT POLISH LAW
}

\author{
Prof. Agnieszka Góra Błaszczykowska*
}

\begin{abstract}
The right to information is one of the most important components of civil rights. Information concerning the law is of special importance. It allows to protect the rights of citizens. The lack of information on the civil rights or barrier to get it leads to the inability to use them when needed and at worst to their violations. Poland, undergoing crucial political, economic and social (generally successful) transformation over the last 3 decades represents an interesting case to analyse. Its legal system has been changed considerably resulting from the shift from central planning to market economy system, fast economic growth as well as accession to EU. It resulted in many inevitable changes in the Polish law concerning also civil rights including the ways to access information on the law. The author presents the court system in Poland and explains why their rather complicated division and competence makes it difficult to identify the competent one. Then the author analyses the ways of obtaining information on the content of the law in Poland and entities that deal with providing them. The legal support in Poland could be divided into general and personal, precourt and court one. Generally, legal support is given by advocates (barristers) or legal advisors. In some court cases legal support could be given by other professionals, for example, tax councellors. These professionals' advices are paid. There is a problem for those people in Poland, whose financial status is so bad they cannot afford for professional legal advice. Lack of knowledge on the rights often causes pushing citizens on the margins of society, generates unnecessary costs or lack of income and results in different, negative social effects. Poland currently places a strong emphasis on information about people rights. There are many ways to obtain information about various types of rights, it is possible to get it at many levels and in many aspects. However, despite the many efforts of the government and non-governmental organizations in this field, there is still much to do, still not everyone in need of legal information are aware of the many ways to get information on the law.
\end{abstract}

INTRODUCTION

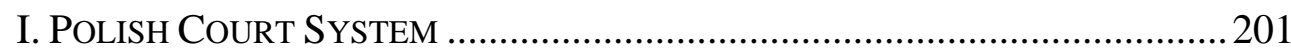

II. Public Available Information ON THE LAW (GENERAL) ................. 201

A. The Role of Media in Disseminating Information on the Law . 201

B. Early Education.............................................................. 203

C. Blogs ...................................................................... 203

\footnotetext{
${ }^{*}$ University of Social Sciences and Humanities, Chodakowska street no19/31, 03-815 Warsaw, Poland. Research fields: Civil Procedure, Civil Law, Family Law and Labour Law.
} 
III. GeNERAL INFORMATION PUblic AVAILABLE (PRE-COURT INFORMATION)

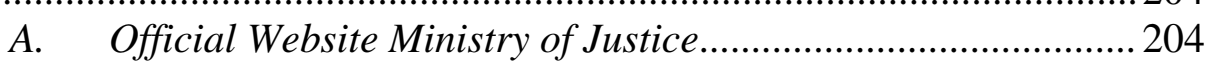

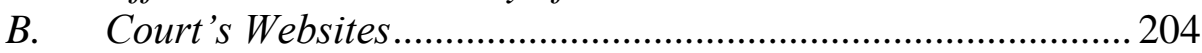

C. Information about Law Made Available by Special Institution 205

D. Lawyers Corporations Actions ................................................206

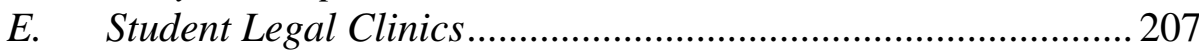

F. Administrative Tax Organs Duties .......................................... 207

IV. INFORMATION ABOUT LAW PROVISIONS AVAILABLE FOR COURT'S

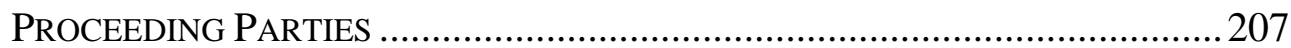

V. INTERPRETATION OF THE LAW PROVISIONS FOR PROFESSIONALS............ 210

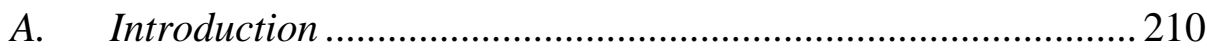

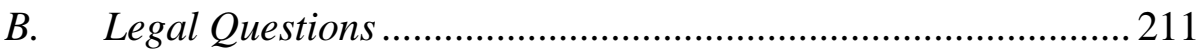

C. Legal Issues Arising in Courts Recognizing Remedies (Other Instance Art. 390 PCPC and 441 CPC).

D. Legal Issues Arising in the Courts of the Highest Court-Art. $398^{17}$ PCPC and Art. 18 ACPC

E. Application of Art. 79 of the Constitution.................................. 212

CONCLUSIONS

\section{INTRODUCTION}

Nowadays information is more valuable than money. Those who have information do have power. Therefore, the media, especially social media, are called "fourth power". They can influence and shape reality because of the access to information about the surrounding reality.

With information about the law one may very well affect the use of the law by individuals. However, the knowledge and information about the law in Poland are difficult to learn and understand because of the very complicated way of creating it by the Polish legislator. In Poland we use to say that the law is only for lawyers. Language, which is used to write the acts and its provisions are not understandable not only for ordinary people, but sometimes also for lawyers.

It often happens, that meaning of law act provision is the topic of disputes and arguments not only between ordinary people, but also among professional lawyers including judges and courts. Explanation of meaning of law provision could be a topic of question, which common civil court ask the Polish Supreme Court (according to Article 390 of the Polish Civil Procedure Code) and the Polish Constistutional Tribunal (according to article 193 of the Polish Constitution). 
Currently in Poland content and meaning of the law has become almost the primary subject of heated debate and struggle between political fractions, the primary topic of interest of the media and a large part of society. Questioned the previously accepted interpretation of the Constitution and laws, inferring from them the meaning different from the hither to generally accepted.

Poland legislation has a habit of very detailed regulation of all areas of activity and life. Every issue, the problems and the institution has an individual act on the basis of which it exists and operates. Therefore, the current legislative activity of the government and introduced by it changes in the law (by amending the existing laws and the creation of new laws) have been criticized as chaotic, spontaneous and reckless, and not preceded by consultations between the relevant ministries and analysis prepared by professional legislators.

Criticism of such activities and the law itself by media and NGOs is very loud and opinion-making. It affects the public, who-without knowing their content and context-often speak about them, criticize and evaluate them. That is why politicians of various opposition parties, part of the media and members of the public openly criticize the actions of the new government and the ruling party. The biggest objection is the lack of information on the financial impact of legislative changes, which usually are calculated in the course of legislative work ${ }^{1}$. The government defends claims against the necessity of these changes, arguing that they result from both the election promises and the need to repair the defective legislation, introduced by the previous parliament. However, it seems the biggest problem in Poland is a lack of detailed information on planned and implemented legislative changes what is most painful for banks, businesses as well as for practicing lawyers and financial advisors.

The average observer of this quasi discussion does not know the facts, but he knows how to evaluate them and to take a stand against them. Most of the representatives of the Polish media are involved politically on different sides, they do not present the reality in an objective manner, instead of giving the public the facts they offerthe comments to them. The mode of action of the media in Poland can be illustratively described as follows: "They do not tell you what happened, but indicate how to assess what happened."

\footnotetext{
${ }^{1}$ For example there's no public available detailed calculation on financial consequences on Act about state aid in upbringing children, from February 11, 2016 (Dz.U. z 2016 r. poz. 195), which is called "Act 500+" because it gives families 500 zloty (PLN) for childmothly (under some specific conditions).
} 
The right to information is one of the most important components of civil rights. The problem will arise while considering which way to inform on the law so that citizens can benefit from this information and properly conduct their own affairs, to decide whether to take business, calculate risks and costs thereof; decide whether to work or improve their education, to ensure the future maintenance of their families etc.

Undoubtly information on the law has very important universal function - allows to protect the rights of citizens. The lack of news on the rights leads to the inability to use the rights and at worst to its violations. Lack of this knowledge sometimes causes pushing citizen on the margins of society, generates unnecessary costs or lack of income, which would reach a person familiar with the law.

Poland currently places a strong emphasis on information concerning people rights: There are many ways to obtain information on various types of rights, it is possible to get it at many levels and in many aspects. Despite the many efforts of the government and non-governmental organizations in this field, there is still much to do, still not everyone in need of legal information is aware of the many ways to get it.

In this article first, the author will present the court system in Poland, because due to their relatively complicated division and competence there is a problem with an identification of the competent court. Then the author will analyse the ways of obtaining information on the content of the law in Poland, and entities that deal with providing it.

The next problem, connected with informing on the law is existing two different lawyer's corporations entitled to represent parties before the court (advocates and legal advisors) and existing different group of professionals, who can represent parties before the court (tax councellors, property managers). The legal support in Poland could be divided into general and personal, precourt and court one. Generally, legal support is given by advocates (barristers) or legal advisors. In some court cases legal support could be provided by other professionals, for example, tax councellors ${ }^{2}$. Of course above mentioned professionals' advices are paid.

There is not any problem to find professional legal advisors for those, whose financial status is good. The problem is for the people, whose financial status is so poor they have not efford for professional legal advice.

The author will focus on some aspects of the right to information on law provisions and the ways of using it by Polish law entities. There are many ways of collecting information on law provision in Poland, for

\footnotetext{
${ }^{2}$ See more in the chapter II concerning polish court system.
} 
example, both kind of courts existiting in Poland have duty to inform parties of the hearings on their rights.

\section{POLISH COURT SYSTEM}

The Polish judiciary system is consisting of two different courts: common and administrative. Common courts recognize civil and criminal cases. Civil cases mean also: labour cases, family cases and commercial cases. Administrative courts are separate branch of court system. They recognize administrative cases concerning, for example, environmental protection law, data protection law, construction law, tax law. The material competence between administrative and civil courts is complex and it is sometimes difficult to understand it by those who are not experts in Polish legal system.

Part of the judgments concerns the cases, which under Polish legal system are classified as personal interest ones under the material competence of common courts. They are issued by district court, then appeal court, and finally by the Polish Supreme Court. The other part of the judgments is issued by district administrative courts and the Polish Supreme Administrative Court. Some of judgments, connected with freedom of expression are issued by common (civil court) and administrative courts, which are also (in some cases) competent in this matter.

It should be underlined that in view of the above mentioned duality of Polish courts system, some legal problems-in case of necessity to prosecute a claim in court will be settled by common or administrative courts. It explains the necessity of analyses of the judgements of two different kinds of courts $^{3}$. These analyses should be provided by professionals, because those who are not professional, facing serious problem with proper understanding the reasons of judgements issued by some courts.

\section{PUblic Available INFORMATION ON THE LAW (GENERAL)}

\section{A. $\quad$ The Role of Media in Disseminating Information on the Law}

There are a number of websites where everybody can get information on current legislation in Poland. This way of getting information is so important, since it does not require financial outlays and is not depending on

\footnotetext{
${ }^{3}$ The author has already written an article with details about Polish court system for IAPL Stambul Conference Papers, which will be published.
} 
the place of residence in search of information. Therefore, the availability of information on the law for anyone, regardless of financial status is essential for the protection of the rights of individual citizens.

The media plays an important role in Poland in terms of informing on the law and protecting the rights of citizens. Their informative role includes not only presenting information on the Polish legislation in force, but also making it available to the public the interesting cases decided by the courts. Some daily newspapers have special pages devoted to legal issues, there are journalists who attend hearings in the courtrooms and presenting press releases from there. This way the public is informed free of charge on the current court decisions, the most interesting cases and issued judgments.

Media have a significant impact on the shape of the legislation. In Poland, the media are able to exert such a significant influence on politicians, that in fact they can influence the law.

For example the lobbying and pressure of media campaign resulted in entry into force of the act of proceedings against the persons with mental disorder creating the danger to life, health and sexual freedom of other people, which entered into force in 22 January 2014. In fact the only reason to form this act was so called "Trynkiewicz case". Mariusz Trynkiewicz is the man who raped and murdered four boys in 1988 and he was sentenced to death. Then few years later, the Polish criminal code was changed (amended) and his penalty was converted to 25 years imprisonment. He completed his imprisonment on 11 February 2014.

From the beginning of the year 2014, all Polish media, expecting his release, launched broad campaign against this man, demanding continuation of his isolation from the society.

The above mentioned act envisages the possibility of isolation of person accused on sexual children harasment, after termination of his penalty, by putting him into special, closed, medical center or arranging for him police supervision.

The case of Trynkiewicz revails unprecedented power of media being in a position to make some important legal acts to come into force by their persistent campaigning and lobbying.

General information about the law and the ways of its implementation on specific issues is available on the websites of the entities and bodies such as the Ombudsman, the Ombudsman for Children, the Insurance Ombudsman, the Ombudsman for Patients' Rights, Consumer Ombudsman. These authorities shall inform on the content of the provisions under which they operate the extent of their competence and how to redress the scope of matters to which they have been called. 
Although there are many options and many readily available sources of information on the law, not everyone in need can reach them.

\section{B. Early Education}

The most important issue is education, providing general information on how to behave in a particular legal situation before there is even a violation of law or before there is a need for legal protection. This is a key aspect of general legal education. This education takes place in schools within the subject "Knowlege about society", ranging from the secondary junior school through secondary senior school.

Currently, it seems that the best overall knowledge of the law have older children and adolescents. In schools there are organized talks and lectures on the law, granted by police, lawyers, volunteers of various institutions and NGOs.

This impression on the limited social group having information on the law are not exaggerated, as evidenced by another, put into force laws, to improve the legal awareness of citizens.

Started from January 1, 2016, the brand new provisions came into force in Polish law related to free of charge legal suport. According to the provisions of this act, public administration organs are obliged to educate their society to improve the level of law knowledge and facilitate access to information on the rights.

The Act provides, inter alia activities aimed at shaping the legal awareness of citizens. According to the Act, public administrations in carrying out their tasks related to public legal education will be obliged to undertake educational activities aimed at enhancing the legal awareness of society.

Tasks which are the subject of discussed issues will be implemented by public interest organizations, as well as institutions offering higher education with the law faculty, professional associations of lawyers, solicitors, notaries, bailiffs and tax advisors - selected in an open tender procedure ${ }^{4}$.

A lot of interests in Poland are TV programs to disseminate legal knowledge about the operation of courts and other judicial and civil rights.

C. Blogs

In Poland, there are several different blogs, in particular concerning

\footnotetext{
${ }^{4}$ Details on this Act is contained in section IV of the text.
} 
information on the law and how to claim. Most of them are in fact advertorial law firms, for lawyers and legal advisors cannot officially advertise, and therefore leads blogs, which provide quasi-legal advice, general advice, thereby encouraging customers to use their services.

\section{GENERAL INFORMATION PUbliC AVAILABLE (PRE-COURT INFORMATION)}

\section{A. Official Website Ministry of Justice}

Much of the information on the law and about ways of doing things about the legal sense is on the official websites of ministries, particularly the Ministry of Justice. One can get the information on specific laws and other legal acts. It also includes on-line access to land registers and other registers kept by the Ministry. On the website of the Ministry, one can also download forms needed to initiate and investigation of cases before the courts.

\section{B. Court's Websites}

Courts in Poland maintain websites with information on the type of caseload, reveal statistics on the number and duration of proceedings. It is important for potential parties have information on costs, because many times their level depends on the decision to open the proceedings. Court costs in Poland are very different depending on the type of case and the court has jurisdiction to hear it. These costs are quite high-when it comes to the civil courts, but e.g. employee or insured claims coming before the labour court and social security do not bear the costs. The costs are not bear by the party seeking alimony before a family court.

On the websites of courts, it is possible to download files, someone needs to take action and apply for exemption from court fees and the establishment of legal aid. In offices filing courts application forms are available (on the same subject) as well as e.g. legal remedies and other pleadings needed to independently pursue the case by people who are not professional lawyers.

Moreover, the courts maintain websites which provide judgments issued in specific cases, together with the justifications. Despite anonymization they have significant cognitive and informative value of the case-law in a particular type of case. Information about the contents of sentences issued in certain cases is useful not only for potential sites, but also for scientists who based on their analysis can lead scientific research. 


\section{Information about Law Made Available by Special Institution}

Started from January 1, 2016, in Poland come into force brand-new provisions in Polish law related to free of charge legal suport.

The act of free of charge legal support from August 5, 2015 enabled free of charge legal support to be given by community (borough) or county (district) (art. 8.1). They engage atorney or legal advisor (art. 6.1) and make a deal with him. This free of charge legal support is given to natural person (according to art. 4.1) for example whose age is below 26 years or who completed 65 years old, and their financial status is poor, big family card holder ${ }^{5}$, combatants, veterans.

According to art. 3.1, free of charge legal assistance covers among others informing the eligible person on its binding legal status, on the rights it is entitled to, on its obligations, on the ways to solve its legal problems and/or drawing up the letter requesting for the exemption from the court fees or establishing ex-officio representative in the court procedure or establishing advocate, legal advisor, tax councellor or patent advisor in administrative court proceedings. However legal aid does not cover preparation of the court letters in a precourt or court proceedings as well as the letters in the administrative court proceedings (art. 3.1.3).

Free of charge legal aid does not cover taxation cases related to business activity, customs, foreign currency and commercial law with the exception of the matters related to preparations for commencing such activity (art. 3.2).

Since January 2016, more than 1,500 points throughout Poland, where professionals provide legal assistance had been created. Thanks to the cooperation of the government, local authorities and NGOs the nation wide system guarantee free access to legal adviceat the local level, thereby eliminating financial barrier to access to professional legal services too often occurring in Poland. Such a large number of free legal aid points are expected to abolish barriers to obtaining information on rights by people residing outside large cities in Poland. It is because in big cities, as already noted, access to free legal aid is facilitated by the existence of a number of entities and organizations engaged in the providing (legal corporations, arranging "days of free legal assistance", advocates of consumer, patient advocates, student legal clinics).

The fact that free legal assistance is a task assigned to government administration will unify the rules of granting it. Funds for the implementation of tasks come from the state budget, which guarantees a

\footnotetext{
${ }^{5}$ Big family in Poland it is family with 3 and more children.
} 
permanent source of funding. Free legal assistance is granted at the points specified by the local government units.

An important element of the system is NGOs. Because of their experience and achievements, there is a possibility of entrusting them to keep $50 \%$ of the free legal aid points. On a national scale the rise in total of more than 1,500 such points is envisaged.

Free legal aid is provided by advocates and legal advisors as well as, in particularly justified cases, applicants ${ }^{6}$ authorized respectively-by the legal advisor or advocate providing free legal aid. However, in the points run by non-governmental organizations legal advices can also be provided by tax advisors and legal studies graduates (with at least three years experience, article 11.3.2).

Free legal assistance will be provided at points in the average rate of 5 days per week for at least 4 hours a day. Information about a specific location and opening hours of the points can be found in the Public Information Bulletin county authorities.

Legal aid consists of:

- Release of information about the current state of the law, vested rights or incumbent obligations;

- Presentation of proposals on how to resolve the legal problem;

- Assistance in preparing a draft letter to the extent necessary to grant legal aid (not include the pleadings in the proceedings or prosecutions and letters in the judicial-administrative proceedings - then the person entitled may request the establishment of ex-officio legal aid);

- Drafting pleading for exemption from court fees or to appoint a representative from the office.

\section{Lawyers Corporations Actions}

Corporations Law, unable to advertise, take different actions, aimed at promoting their services. They organize days of granting free legal aid, carried out various forms of legal education in schools in order to familiarize the participants of their rights and possibilities of using them in certain situations.

As already mentioned, these actions are carried out mostly in the cities, which are the seats of these corporations, and thus in large and medium cities. Residents of small towns and villages, away from larger centers, have limited access to free legal aid and professional lawyers.

\footnotetext{
${ }^{6}$ Lawyers who intend to obtain advocate or advisor status.
} 


\section{E. Student Legal Clinics}

In addition, multiple legal clinics at law faculties of universities are run, where also free information about law may be obtained, but essentially it is used only by the inhabitants of the cities, where the departments of law are located. Keeping these centers is beneficial for students who learn in their profession as well as for the people who can benefit from the assistance of experienced lawyers who approve projects writings and tips provided by the students.

\section{F. Administrative Tax Organs Duties}

Right to be informed on meaning of provision of Polish tax law could be realised by asking Polish tax administration for "individual tax law interpretation" (article 14b of the Polish Tax Ordinance). This interpretation is binding both for administration tax organ and tax-payer as long as administrative court will not eliminate it by issuing the sentence. Unfortunatelly, also administrative tax organ could change it by sending its second one own interpretation, so tax-payer could not be sure how long exactly the validity of this individual interpretation will last.

\section{INFORMATION ABOUT LAW PROVISIONS AVAILABLE FOR COURT'S PROCEEDING PARTIES}

First, one should note the obligation of the courts, adjudicating in civil matters, providingthe parties with instructions about the proceedings. In accordance with art. 5 Polish Civil Procedure Code (PCPC), it is possible, should it prove necessary, but the party must appear on without a lawyer, patent attorney or counsel Attorney-General of the Treasury ${ }^{7}$. A similar obligation has been imposed in art. $212 \S 2$ (PCPC) under which, in case of a justified need, the judge may give the parties the necessary instruction and according to the circumstances draws attention to the desirability of establishing a legal representative.

In accordance with art. 6 Administrative Court Proceding Code (ACPC) the administrative court, in the event of justified need, gives the parties occuring in the court without a lawyer, tax advisor or patent advisor, the relevant instuctionsnecessary for legal proceedings as well as teachings on consequences of their negligence.

\footnotetext{
${ }^{7}$ See more at: A. Góra- Błaszczykowska in: A. Góra- Błaszczykowska, Kodeks postępowania cywilnego. Komentarz. Art.1-729, 2 edition, Warsaw 2016, at 69-71;
} 
The cited provisions are intended to level the chances of the parties acting without a professional lawyer.

Suggestions and instructions concerning the procedural steps that should be taken on; how and in what timeframe the court should determine the defects in these proceedings as well as what are the legal consequences of failure to remedy these deficiencies within the time limit.

The court instructions must be given in such a way that the party who does not benefit from the assistance of professional lawyer has not been deprived of opportunities to influence the ongoing court case and thus realize their own rights. The regulations do not require the court to instruct the party on action to be taken in case of negligence in order to reduce their impact.

The principle of information in criminal proceedings is governed by article 16 Polish Criminal Procedure Code (CPC). According to its $\S 1$, if the authority conducting the proceedings is obliged to instruct the parties on the obligations incumbent and about their rights, the lack of such instruction or erroneous instruction may not cause negative effects on the process for the defendant or other person to whom it applies.

Pursuant to art. $16 \S 2 \mathrm{CPC}$, the authority conducting the proceedings should also, where necessary, provide participants with information on the procedure responsibilities and on their rights also in the cases where the law clearly does not constitute such an obligation. In the absence of such instruction when, in the light of the circumstances of the case it was indispensable, or erroneous instruction, $\S 1$ shall be applied accordingly.

The provision of art. $16 \S 2 \mathrm{CPC}$ does not oblige the authorities of the process to ensure the wider interests of the parties, and only a duty to inform them of these rights and duties that are directly connected to the content of published rulings, decisions, actions ${ }^{8}$.

In terms of proceedings in criminal matters, pursuant to art. $386 \S 2$ $\mathrm{CPC}$, after questioning the accused the judge instructs him of his right to ask questions to the examined persons and to be given explanations for any evidence.

The provisions of art. $386 \mathrm{CPC}$ are repeating the rights of the accused, referred to in the general provision of article $175 \S 1$ and 2 CPC, in relation to proceedings at the trial. Immediately after the reading of the indictment the judge instructs the accused of the right to provide explanations, the right to refuse to be heard, as well as the right to refuse to answer the questions asked him. The judge also asks him if he admits to the act, and if he wants

\footnotetext{
${ }^{8}$ Judgement of District (second instance) Court in Warsaw-II Penal Departement June 7th, 2013 r. number II AKa 163/13.
} 
to make any explanations.

In case of need, depending on whether the accused is assisted by counsel and on his personal characteristics, in particular its level of mental development, level of intelligence, and sometimes also other circumstances related to the hearing, that information can and should be more detailed. In particular, often it could be justified to instruct the accused that ithas the right and not an obligation to provide explanations and answer the questions. It means that he may: (1) Reduce his explanations to some circumstances only and refuse their submission in the rest of; (2) refuse to answer only some questions; (3) refuse to answer questions of the court or of the individual designated by himself, but to answer the questions of others, or (4) to respond only to questions of specific person designated by the party, e.g. his defender 9 .

This right already exists in the course of the investigation. In accordance with Art. $175 \S 1$ CPC the accused should be advised of the right to provide explanations and the right to refuse to answer particular questions or refuse to answer questions without giving reasons.

It is highlighted in the literature the Article $175 \S 1$ of the CPC imposed on the judicial body the duty to instruct the accused of his rights concerning providing of explanations. ${ }^{10}$ This obligation is specified in a number of subsequent provisions of the Code, accordingly to the stage of the proceedings.

In the preparatory proceedings the suspect should be instructed on his rights, including the right to provide an explanation, to refuse their submission or to answer the questions, before the first questioning (Art. 300 CPC).

That instruction should be in writing, and its transfer to the suspect should be recorded by submitting his signature. Also on the stage of criminal proceedings Art. $386 \S 1$ of the CPC obliges the presiding judge to instruct the accused after reading the indictment on his right to provide explanations and the possibility of refusal of their submission.

The accused (suspect) should be instructed not only about the right to refuse to answer or answers to question and that he can do so without giving reasons for the refusal, but also the fact that his attitude will have no negative effects on the process for him ${ }^{11}$.

However, there is no obstacle to draw defendant's attention that providing explanations may contribute not only to make findings favorable

\footnotetext{
${ }^{9}$ R. Ponikowski in: J. Skorupka, Commentary to art. 386 k.p.k., Legalis 2015.

${ }^{10}$ D. Gruszecka in: J. Skorupka, Commentary to art. 175 k.p.k., Legalis 2016.

${ }^{11}$ Judgement of the Polish Supreme Court of 4.2.2008 r., III KK 363/07, BPK 2008, No 5, at 27.
} 
to him, but also to accelerate the completion of criminal proceedings with art. 16 of the CPC.

In the above circumstances the judical body noticing this failure should instruct the accused of his rights while before questioning, it should be explained to him that the explanations previously provided by the accused do not constitute evidence and only then re-interrogate the accused.

\section{INTERPRETATION OF THE LAW PROVISIONS FOR PROFESSIONALS}

\section{A. Introduction}

The Polish law system is based on Constitution, acts, codes and others legal acts. There is a general opinion about the poor quality of Polish law, arising from a number of questionable, vague provisions. In December 3, 2015, the Polish Constitutional Tribunal ruled on partial illegality of the act, which has been created (among others) by three judges of this Tribunal ${ }^{12}$. The example given illustrates the complexity of the Polish legislation and the degree of uncertainty as to the correct understanding of the rules by entities applying the law.

This problemis not faced by the Polish judiciary only. In the judgment of the European Court of Human Rights of December 22, 2015 $5^{13}$, it was underlined, that the possibility of conflicting judgments is an inherent trait of any judicial system that is based on the principle of adversarial appeal. This feature cannot be regarded as a manifestation of violation of the Convention. Justifications for the national court decisions cannot be considered arbitrary if only because the use of (unclear) law sometimes requires the interpretation and the possibility of decisions being moved under the means of appeal.

Despite the existance of specific acts and regulations contained in them there is uncertainty as to their significance what results in the fragmentation of the case-law of the Polish courts. The situation is assessed very critically especially when we consider that this diversity is also reflected in the jurisprudence of the highest instance courts, i.e. the Polish Supreme Court and the Polish Supreme Administrative Court.

Justification for the discrepancies in the judgments of Polish courts results from constitutionally guaranteed independence of judges. It constitutes a normative basis for jurisdiction in similar cases regardless already issued judgments. It explains the existing divergence in the case law

\footnotetext{
${ }^{12}$ See for example, judgement number K 34/15, D.U. 2015 position 2129.

${ }^{13}$ Stanković and Trajković against Serbia, No. 37194/08 and 37260/08.
} 
of authorities, adjudicating, e.g. in tax matters.

The problem is the interpretation not only of individual provisions, but also their relationships. In addition, problems of interpretation are faced not only by ordinary citizens and professional lawyers, but by the most prominent judges adjudicating in the Polish Supreme Court and the Polish Supreme Administrative Court as well.

\section{B. Legal Questions}

A very high degree of complexity of the legislation makes it possible for the courts of a particular civil case to request for a binding interpretation of the law by the Polish Supreme Court when the court of second instance recognizes the appeal (art. 390 PCPC). According to this article, if while recognizing the appeal there is a legal issue rising serious doubts, the court may submit the issue to be resolved by the Polish Supreme Court, delaying the case.

The Polish Supreme Court is competent to take the case for its recognition or to pass the issue to be resolved in extended composition of the Court. The resolution of the Polish Supreme Court concerning the specific legal issue is binding in the case. Also the three judges of the Polish Supreme Court may refer the question to the enlarged composition of that court $^{14}$.

According to article 193 of the Polish Constitution, each court may submit to the Polish Constitutional Tribunal a question of law as to the conformity of a normative act to the Constitution, ratified international agreements or statute, if the answer to that question of law will determine an issue currently before the court.

The quoted provision is an example of doubts concerning the law, not only in the domain of non-professionals, but also the courts of all instances. Provided for in art. 193 of the Polish Constitution legal question can ask any court, not only common, but also the Polish Supreme Court and the Polish Supreme Administrative Court.

C. Legal Issues Arising in Courts Recognizing Remedies (Other Instance Art. 390 PCPC and 441 CPC)

As the first, one should indicate the provisions of art. 390 PCPC and art. $441 \mathrm{CPC}$ allowing the courts of second instance, to present to the Polish

\footnotetext{
${ }^{14}$ See more at A. Góra- Błaszczykowska in: A. Góra- Błaszczykowska, Kodeks postępowania cywilnego. Komentarz. Art. 1-729, 2 edition, Warsaw 2016, at 1021 and next.
} 
Supreme Court the legal issue raising serious doubts that arose in recognition of the appeal. In both types of proceedings, the Polish Supreme Court may refer the legal issue to be resolved in extended composition of this Court (art. $390 \S 1$ sentence 2 of the PCPC and art. $441 \S \mathrm{CPC}$ ), the Polish Supreme Court may take the case for recognition (art. $390 \S 1$ PCPC and art. $441 \S 5 \mathrm{CPC}$ ).

Accomplishing intepretation is used until it is changed by other committee of the Polish Supreme Court.

D. Legal Issues Arising in the Courts of the Highest Court-Art. $398^{17}$ PCPC and Art. 18 ACPC

Highest Instances Courts - the Polish Supreme Court and the Polish Supreme Administrative Court may also submit legal issue to be resolved in extended composition of the Courts, if this issue emerges when recognizing cassation (Art. $398^{17} \S 1$ PCPC and Art. $187 \S 1$ ACPC). The resolution of the Polish Supreme Court in extended compositionis is binding for the case (Art. $398^{17} \S 2$ PCPC and Art. 187 § 2 ACPC). The Polish Supreme Court or the Polish Supreme Administrative Court in extended composition may take the matter for their recognition (Art. $398^{17} \S 3$ PCPC and Art. $187 \S 2$ ACPC) ${ }^{15}$.

A similar solution lies in art. 60 of the Act on the Polish Supreme Court. If in the case law of common courts, military courts or the Polish Supreme Court they reveal discrepancies in interpretation of the law, the First Chairman of the Supreme Court may submit a request for the decision to the Supreme Court composed of seven judgesor other suitable composition (§1).

According to $\S 2$, the application referred to in $\S 1$, may also be submitted by Ombudsman and the Attorney General as well as, within its jurisdiction, the Ombudsman for Children, the Chairman of the Social Dialogue, Chairman of the Financial Supervision Commission.

\section{E. Application of Art. 79 of the Constitution}

According to art. 79.1 of the Polish Constitution, anyone whose constitutional freedoms or rights have been violated has the right, under the terms of the Act, to submit the complaint to the Polish Constitutional Tribunal on the constitutionality of a law or other normative act under

\footnotetext{
${ }^{15}$ See more at: A. Góra- Błaszczykowska in: A. Góra- Błaszczykowska, Kodeks postępowania cywilnego. Komentarz. Art.1-729, 2 edition, Warsaw 2016, at 1104 and next.
} 
which a court or organ of public administration has made a final decision on his freedoms or rights or on his obligations specified in the Constitution.

\section{CONCLUSIONS}

In the above circumstances the issue of ways of information on the rights and their impact on the protection of rights in Poland is a very important practical question.

Since the statutory law is understood in divergent uneven manner, which is expressed by divergent court rulings, so how the entities should take knowledge of the law? How they should shape their goals and plans for a legal sense, since they are not sure about what rights they enjoy and that those ones granted to them by one law will not be picked up by another law?

Therefore, in the Polish context, one of the major problems for the people is obtaining information on the law, which allows for the protection of their rights. Of course, people with high material status may hire professional lawyers and allocate sufficient money to assert their rights before the court. However, people with lower financial status must obtain information on the law in a different way.

There is an especially high correlation in Poland between the financial standing of individuals and their possibility of defending their rights. The right to information on law can be fully used only by the people with good financial status. The actions of the government and various nongovernmental organizations must aim at creation of such conditions and methods of informing the people on their civil and private rights that enable everyone whose rights have been violated to obtain legal protection regardless whether or not it has sufficient financial resources to initiate proceedings and to take a lawyer.

Information on law also requires the use of language and vocabulary adapted to education and intellectual abilities of the recipient. This is particularly important in Poland, where the process of formulating standards and regulations is very complicated and difficult, causing a problem of interpretation, not only among the addressees of legal norms, but sometimes even among professional lawyers. 